\title{
Double Ligand-Enabled Ni-Catalyzed C-H Alkenylation of Amines with Alkynes
}

\author{
Wei-Wei Yao, ${ }^{\dagger}$ Ran Li,${ }^{\dagger}$ Hao Chen, ${ }^{\dagger}$ Ming-Kai Chen, ${ }^{\dagger}$ Yu-Xin Luan, ${ }^{\dagger}, *$ Yi Wang, ${ }^{\dagger}$ Zhi-Xiang Yu,,$* *$ \\ Mengchun $\mathrm{Ye}^{\dagger, *}$ \\ †State Key Laboratory and Institute of Elemento-Organic Chemistry, College of Chemistry, Nankai University, Tianjin 300071, China \\ \$Beijing National Laboratory for Molecular Sciences (BNLMS), Key Laboratory of Bioorganic Chemistry and Molecular Engineering of \\ Ministry of Education, College of Chemistry, Peking University, Beijing 100871, China
}

Supporting Information Placeholder

\begin{abstract}
A nickel-catalyzed $\mathrm{C}-\mathrm{H}$ alkenylation of amines with alkynes was developed, providing a series of allylic amines in up to $94 \%$ yield. The use of bulky amino protecting group (triisopropylphenylsulfonyl) and double ligands (IPr and $\mathrm{PCy}_{3}$ ) proved critical to the reaction efficiency.
\end{abstract}

Transition metal-catalyzed direct $\alpha-\mathrm{C}-\mathrm{H}$ functionalization of amines provides rapid access to various functionalized amines that widely exist in bioactive compounds and materials. ${ }^{1,2}$ Despite relatively difficult activation of $\mathrm{sp}^{3} \mathrm{C}-\mathrm{H}$ bonds, ${ }^{3}$ especially ubiquitous secondary $\mathrm{sp}^{3} \mathrm{C}-\mathrm{H}$ bonds that are more resistant to transition metal insertion, ${ }^{4}$ great progress has been achieved in alkylation, ${ }^{5-7}$ arylation, ${ }^{8}$ and other functionalization reactions ${ }^{9}$ for a broad range of $\alpha$-secondary $\mathrm{sp}^{3} \mathrm{C}-\mathrm{H}$ bonds. Nevertheless, $\mathrm{C}-\mathrm{H}$ alkenylation of amines with alkynes still remains as a formidable challenge, ${ }^{10-14}$ probably owing to the instability of the produced allylic amines, as well as easy coordination of alkynes to metals. Although directing group-enabled Ir-catalyzed reactions allowed $\mathrm{C}-\mathrm{H}$ alkenylations of amines with alkynes via oxidative addition pathway, these methods was quite sensitive to the steric hindrance of amines, rendering reported reactions compatible with in general less sterically hindered primary amines. ${ }^{11,12}$ In order to accommodate a broader range of substrates, another distinctive pathway that underwent through $\eta^{2}$-imine complex was devised. In 1989, Buchwald and co-workers reported the first non-chelated alkenylation of secondary amines with alkynes. They found that zirconocene complex can effectively join two substrates into allylic amines (Scheme 1a), ${ }^{13}$ while four steps and a stoichiometric amount of the $\mathrm{Zr}$ reagent were required. Since that, much effort has been devoted to improving this reaction, ${ }^{14}$ while none of them could unify the four steps in one reaction and could reduce the loading of metals to a catalytic amount. During our submission, Schafer group reported a bis(ureate)-enabled Zr-catalyzed alkenylation reaction for the first time (Scheme 1b). ${ }^{15}$ Despite this advance, the $\mathrm{Zr}$-catalyzed system still suffered from harsh conditions $\left(145^{\circ} \mathrm{C}\right)$ and limited scope of amines and alkynes. Herein, we used inexpensive nickel as a catalyst to achieve direct $\mathrm{C}-\mathrm{H}$ alkenylations of amines with alkynes, providing a series of allylic amines in up to $94 \%$ yield (Scheme $1 \mathrm{c}$ ). ${ }^{16}$ The use of bulky Nprotecting group and the combination of $\mathrm{N}$-heterocyclic carbene (NHC) and phosphine ligands proved critical to the reaction efficiency, not only leading to relatively mild conditions, but also significantly expanding substrate scope.

Scheme 1. Transition Metal-Catalyzed $\alpha$-Alkenylation of Amines with Alkynes a) Stoichiometric Zr-catalyzed C-H alkenylation of amines with alkynes (Buchwald)

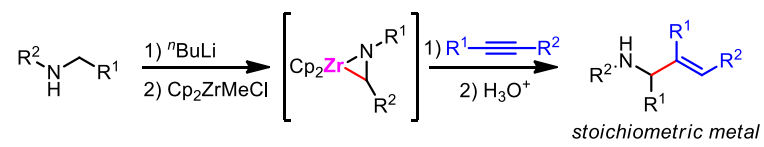

b) Zr-catalyzed C-H alkenylation of amines with alkynes (Schafer)

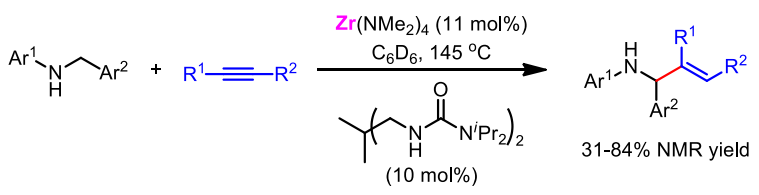

c) Ni-catalyzed $\mathrm{C}-\mathrm{H}$ alkenylation of amines with alkynes (this work)

$$
\text { TPS }=\text { triisopropylphenylsulfonyl }
$$

Redox-neutral coupling of alcohols and alkynes elegantly developed by Matsubara ${ }^{17}$ and Krische ${ }^{18}$ groups provided an efficient pathway for direct $\alpha$-functionalization of alcohols, while the similar coupling of amines and alkynes remains unsolved. We ascribed the difficulty to the following challenges: (1) strong basicity and nucleophilicity of amines could deactivate transition metals; (2) relatively difficult $\beta$-H cleavage of amines and instability of the in situ generated imine intermediates; (3) easy oligomerization of alkynes and facile addition of amines to alkynes. Therefore, we envisioned that the selection of a proper amino protecting group could reduce the basicity of amines, preventing catalyst deactivation and other side reactions. Following this hypothesis, we conducted extensive investigation of $\mathrm{N}$-protecting groups, together with transition metals, ligands, and other reaction parameters. Ultimately, we found that triisopropylsulfonyl (TPS) was the superior protecting group, with which a redox-neutral and atom-economical coupling of secondary amide $\mathbf{1 a}$ with alkyne $\mathbf{2 a}$ was achieved for the first time, providing the corresponding allylic amide 3a in nearly quantitative yield as determined by ${ }^{1} \mathrm{H}$ NMR (Scheme 2, entry 1). Control experiments showed that any alteration of TPS resulted into significantly diminished yields (entries 2-8). For example, the change of isopropyl groups (TPS) into methyl groups (TMS) gave only $9 \%$ yield (entry 2 ). Common p-tolylsulfonyl (Ts) further decreased the yield to only a trace amount (entry 3). The combination of NHC (IPr) and phosphine $\left(\mathrm{PCy}_{3}\right)$ ligands also proved critical to the reaction (entries 9-17). The absence of IPrHCl completely inhibited the reaction (entry 9), whereas the reaction still gave $\mathbf{3 a}$ in $14 \%$ yield without the addi- 
tion of $\mathrm{PC}_{3}$ (entry 13), demonstrating the vital role of IPr and the promoting effect of $\mathrm{PCy}$. In fact, a yield of $68 \%$ was detected with IPr alone at an elevated temperature $\left(110^{\circ} \mathrm{C}\right)$ but with poor reproducibility (see Supporting Information for details). Other carbenes and phosphines were less effective (entries 10-12 and 14-17). The absence of $\mathrm{Ni}(\operatorname{cod})_{2}$ or replacement of $\mathrm{Ni}(\operatorname{cod})_{2}$ by other nickel precatalysts gave almost no product (entries 18-20).

\section{Scheme 2. Reaction Optimization ${ }^{a}$}

\begin{tabular}{|c|c|c|c|}
\hline 1a & 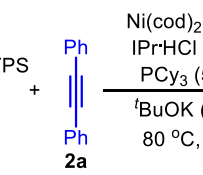 & $\underset{\substack{\text { luene } \\
\text { luene) }}}{\mathrm{mol} \%)}$ & (PPS \\
\hline entry & deviation from the $s$ & ndard conditions & yield of $\mathbf{3 a}(\%)$ \\
\hline 1 & nod & iation & 99 \\
\hline 2 & TPS replaced by & $2,4,6-\mathrm{Me}_{3}-\mathrm{C}_{6} \mathrm{H}_{2} \mathrm{SO}_{2}$ (TMS) & 9 \\
\hline 3 & & $p-\mathrm{Me}-\mathrm{C}_{6} \mathrm{H}_{4} \mathrm{SO}_{2}(\mathrm{Ts})$ & trace \\
\hline 4 & & $p-\mathrm{CF}_{3}-\mathrm{C}_{6} \mathrm{H}_{4} \mathrm{SO}_{2}$ & 7 \\
\hline 5 & & $p-\mathrm{MeO}-\mathrm{C}_{6} \mathrm{H}_{4} \mathrm{SO}_{2}$ & trace \\
\hline 6 & & $\mathrm{CH}_{3}-\mathrm{SO}_{2}(\mathrm{Ms})$ & 7 \\
\hline 7 & & $\mathrm{CF}_{3}-\mathrm{SO}_{2}(\mathrm{Tf})$ & 0 \\
\hline 8 & & ${ }^{t} \mathrm{Bu}-\mathrm{SO}_{2}(\mathrm{Bs})$ & 0 \\
\hline 9 & $\mathrm{IPr} \mathrm{HCl}$ replaced by & 0 & 0 \\
\hline 10 & & $\mathrm{IPr}^{\mathrm{Me}} \cdot \mathrm{HCl}$ & 76 \\
\hline 11 & & $\mathrm{SIPr} \cdot \mathrm{HCl}$ & 20 \\
\hline 12 & & IMes $\mathrm{HCl}$ & 34 \\
\hline 13 & $\mathrm{PCy}_{3}$ replaced by & 0 & 14 \\
\hline 14 & & $\mathrm{Ph}_{3} \mathrm{P}$ & 51 \\
\hline 15 & & ${ }^{t} \mathrm{Bu}_{3} \mathrm{P}$ & 17 \\
\hline 16 & & ${ }^{n} \mathrm{Bu}_{3} \mathrm{P}$ & 11 \\
\hline 17 & & dppe & 17 \\
\hline 18 & $\mathrm{Ni}(\operatorname{cod})_{2}$ replaced by & 0 & 0 \\
\hline 19 & & $\mathrm{NiCl}_{2} \cdot$ diglyme & 0 \\
\hline 20 & & $\mathrm{NiCl}_{2}$ 'diglyme with $\mathrm{Mn}$ & 0 \\
\hline
\end{tabular}

${ }^{a}$ Reaction conditions: 1a $(0.20 \mathrm{mmol}), \mathbf{2 a}(0.22 \mathrm{mmol})$, toluene $\left(2.0 \mathrm{~mL}\right.$ ) under $\mathrm{N}_{2}$ for $1 \mathrm{~h}$; yield was determined by ${ }^{1} \mathrm{H}$ NMR using $\mathrm{Cl}_{2} \mathrm{CHCHCl}_{2}$ as the internal standard.

Under the optimized conditions, various $N$-TPS amides were then examined (Scheme 3). Results showed that the reaction tolerated a broad range of functional groups on the phenyl ring of $N$ benzyl amides, including simple alkyl (Me, 3b-3d), electrondonating groups (alkoxy, 3e, and $\mathbf{3 f}$ ), and electron-withdrawing groups $\left(\mathrm{OCF}_{3}, \mathrm{~F}, \mathrm{Cl}, \mathrm{CF}_{3}, \mathrm{CN}\right.$, and $\left.\mathrm{CO}_{2} \mathrm{Me}, \mathbf{3 g}-\mathbf{3 n}\right)$, providing the corresponding allylic amines in $62-94 \%$ yields. In addition, the position of substituents did not have a strong influence on the reaction yield (3b-3d and $\mathbf{3 h}-\mathbf{3 j})$. Notably, both 1-naphthyl (3o) and heteroaryl (3p) instead of the phenyl of 1a also worked well, affording both $86 \%$ yields. When the phenyl was replaced by the alkenyl, a decreased yield was obtained $(45 \%, 3 \mathbf{3 q})$ in the presence of $10 \mathrm{~mol} \%$ of the catalyst at $110{ }^{\circ} \mathrm{C}$. Notably, various $\mathrm{N}$ alkylamides were still compatible with the reaction $(\mathbf{3 r}-\mathbf{3 u}$, $41-54 \%$ yields), but requiring harsher conditions $\left(130{ }^{\circ} \mathrm{C}\right.$ and 20 mol\% catalyst) and a Ts protecting group.

Next, a broad range of alkynes were investigated under the standard conditions (Scheme 4). Various diaryl alkynes bearing alkyls (4a-4d) and electron-donating groups (4e and $\mathbf{4 f})$ on the phenyl rings were well compatible with the current reaction, providing the corresponding products in $79-92 \%$ yields. Notably, 2-tolylalkyne gave a 1:1 mixture of $E: Z$ isomers $(\mathbf{4 c})$, probably because the significant steric hindrance on the aryl ring forced the alkene to isomerize. In contrast, electron-withdrawing groups such as $\mathrm{OCF}_{3}(\mathbf{4 g}), \mathrm{F}(\mathbf{4 h})$, and $\mathrm{CF}_{3}(\mathbf{4 i})$ on the phenyl ring led to slightly lower yields even at a higher temperature. In addition, both dialkyl alkynes (4j and $\mathbf{4 k}$ ) and alkyl aryl alkynes (4l-4p) were well tolerated, providing both good yields and good to excellent regioselectivities. For example, 1-phenylpropyne gave 8.1:1 regioisomeric ratio (4I), and the change of methyl to ethyl significantly increased the ratio to $20: 1$ (4m). Bulkier alkyls $(\mathbf{4 n}-\mathbf{4 p})$ or silyl $(\mathbf{4 q})$ led to a single regioisomer. However, nonsymmetrical dialkyl alkyne (4r) cannot afford good regioselectivity probably owing to low differentiation between isopropyl and methyl groups.

Scheme 3. Scope of Amides ${ }^{a}$

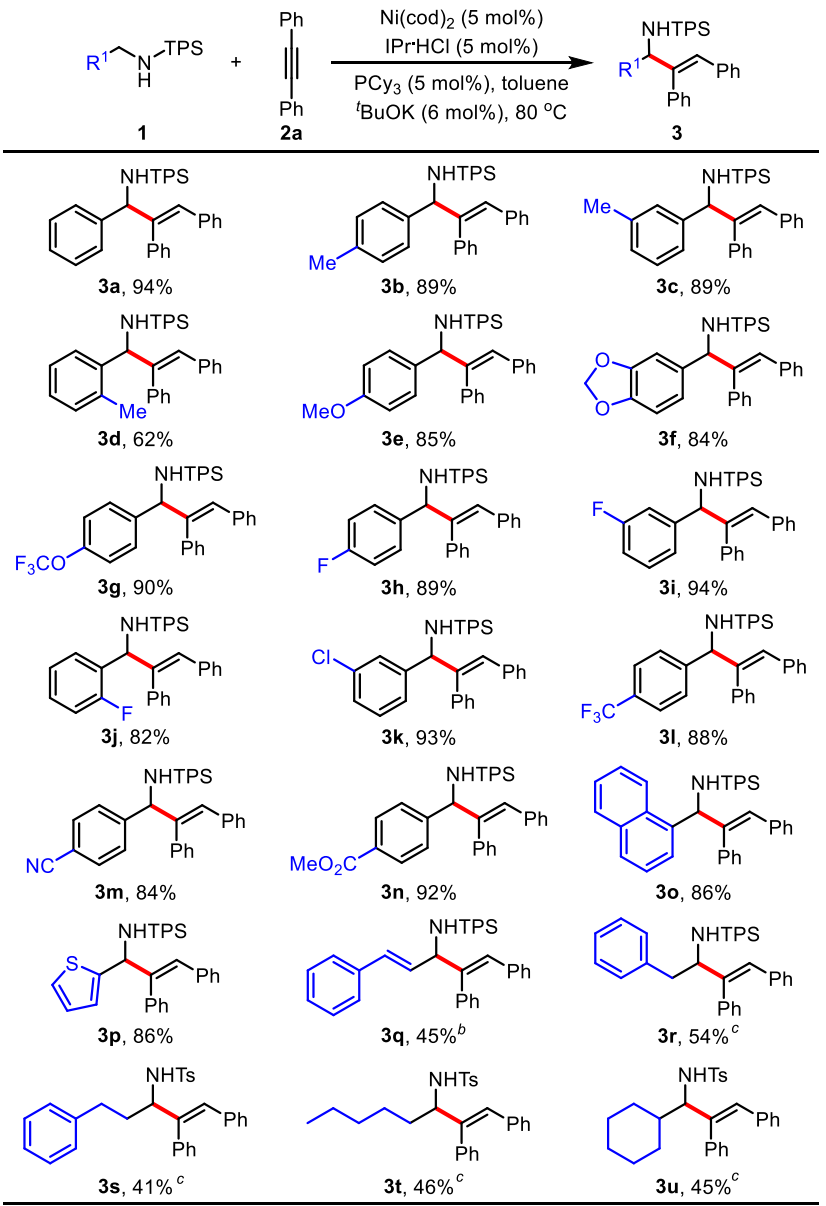

${ }^{a}$ Reaction conditions: $1(0.20 \mathrm{mmol}), \mathbf{2 a}(0.22 \mathrm{mmol})$, toluene (2.0 mL) under $\mathrm{N}_{2}$ for $1-12 \mathrm{~h}$; yield of isolated products. ${ }^{b} \mathrm{Ni}(\operatorname{cod})_{2}(10 \mathrm{~mol} \%)$, IPr $\mathrm{HCl}(10 \mathrm{~mol} \%), \mathrm{PCy}_{3}(10 \mathrm{~mol} \%)$, ${ }^{t} \mathrm{BuOK}(12 \mathrm{~mol} \%)$ at $110{ }^{\circ} \mathrm{C} .{ }^{c} \mathrm{Ni}(\mathrm{cod})_{2}(20 \mathrm{~mol} \%)$, IMes $\mathrm{HCl}(20$ $\mathrm{mol} \%), \mathrm{PCy}_{3}(20 \mathrm{~mol} \%),{ }^{t} \mathrm{BuOK}(22 \mathrm{~mol} \%)$ at $130{ }^{\circ} \mathrm{C}$.

To demonstrate the utility of the reaction, a gram-scale reaction of the model substrates under the standard conditions was conducted, affording the desired product 3a in $88 \%$ yield (Scheme 5a). In addition, the formed allylic amine $\mathbf{3} \mathbf{a}$ can act as a versatile synthetic intermediate to participate into various transformations. For example, hydrogenation followed by deprotection and reprotection provided compound 5 in $68 \%$ yield. Simple oxidation of 3a resulted into $\alpha$-amino ketone $\mathbf{6}$ in $90 \%$ yield.

To gain insights into the reaction mechanism, some mechanistic experiments were carried out. Deuterium labeling experiments revealed that $100 \%$ allylic deuterium and $94 \%$ olefinic deuterium existed in product $\boldsymbol{d} \mathbf{- 3 a}$, suggesting that one benzylic hydrogen atom was transferred to the olefinic position (Scheme 5b, eq (1)). In addition, deuterated $Z$-stilbene was obtained, indicating that a part of alkynes were reduced during the reaction process. Crosso- 
ver experiments between $\boldsymbol{d}$-1a and 1e suggested that the allylic and olefinic hydrogens may originate from different amide molecules (eq (2)), excluding the oxidative addition pathway as shown in Scheme 1a. The observed kinetic isotopic effect $\left(k_{\mathrm{H}} / k_{\mathrm{D}}=2.7\right.$ in the intermolecular competitive reaction and $k_{\mathrm{H}} / k_{\mathrm{D}}=2.2$ in parallel reactions, eq (3)) implied that the cleavage of the benzylic $\mathrm{C}-\mathrm{H}$ bond could be involved in the rate-determining step. Notably, when dimethylamino benzylic amide 1v was used as the substrate, the corresponding imine $\mathbf{1} \mathbf{v}^{\prime}$ was detected (Scheme 5c). Moreover, the competitive reaction between amide $\mathbf{1 a}$ and imine $\mathbf{1} \mathbf{b}^{\prime}$ showed that both of them gave the corresponding products in comparable yields (Scheme 5d). These results suggested that an imine intermediate could be involved in the catalytic cycle. ${ }^{17}$ In addition, the stoichiometric reaction of a five-membered nickelacylce ${ }^{19}$ and amide 1a with or without IPr afforded the desired product $\mathbf{3 b}$ in $68 \%$ and $9 \%$ yields, respectively, suggesting that both the nickelacycle and IPr were critical to the reaction (Scheme 5e).

\section{Scheme 4. Scope of Alkynes ${ }^{a}$}

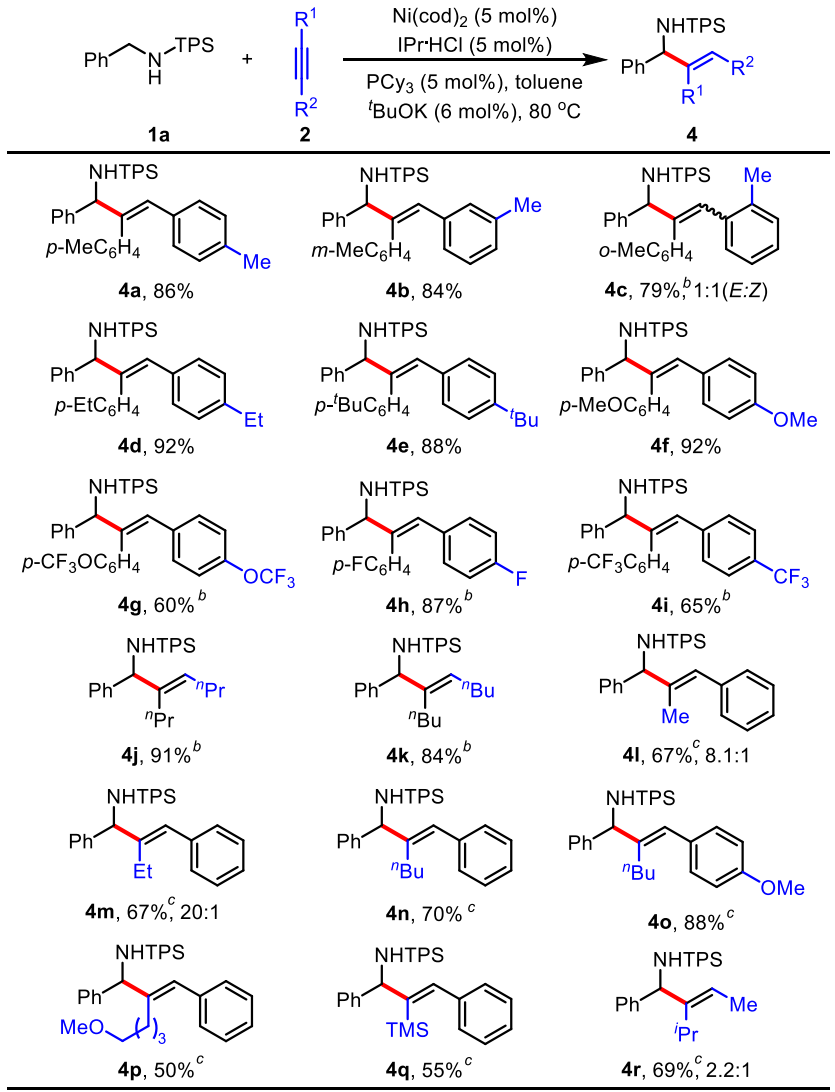

${ }^{a}$ Reaction conditions: 1a $(0.20 \mathrm{mmol}), \mathbf{2}(0.22 \mathrm{mmol})$, toluene $(2.0 \mathrm{~mL})$ under $\mathrm{N}_{2}$ for $1-12 \mathrm{~h}$; yield of isolated products. ${ }^{b} 110{ }^{\circ} \mathrm{C}$. ${ }^{c} \mathrm{Ni}(\mathrm{cod})_{2}(10 \mathrm{~mol} \%)$, IPr $\mathrm{HCl}(10 \mathrm{~mol} \%), \mathrm{PCy}_{3}(10 \mathrm{~mol} \%)$, ${ }^{t} \mathrm{BuOK}(12 \mathrm{~mol} \%)$ at $110{ }^{\circ} \mathrm{C}$ and regioselectivity for nonsymmetrical alkynes.

Based on these mechanistic experiments and previous literature reports, ${ }^{16,17,20}$ a possible mechanism was proposed (Scheme $6)$. At the induction stage, the nickel-catalyzed transfer hydrogenation of alkyne 2a with sulfonamide 1a furnishes $Z$-stilbene and imine 19' $\mathbf{a}^{\prime}$. Then, $\mathbf{1} \mathbf{a}^{\prime}, \mathbf{2} \mathbf{a}$, and the nickel catalyst undergo an oxidative cyclometallation to generate nickelacycle $\mathbf{B}$, which is subsequently protonated by $\mathbf{1 a}$. The resulting intermediate $\mathbf{C}$ then proceeds through a direct intramolecular hydrogen transfer (rather than a stepwise $\beta$-H elimination/reductive elimination pathway; vide post) to give $\mathrm{Ni}$-product complex D. ${ }^{20 \mathrm{a}}$ Finally, catalyst transfer between $\mathbf{D}$ and $\mathbf{2 a}$ occurs, releasing product $\mathbf{3 a}$ and completing the catalytic cycle.

\section{Scheme 5. Product Transformation and Mechanistic Ex-} periments

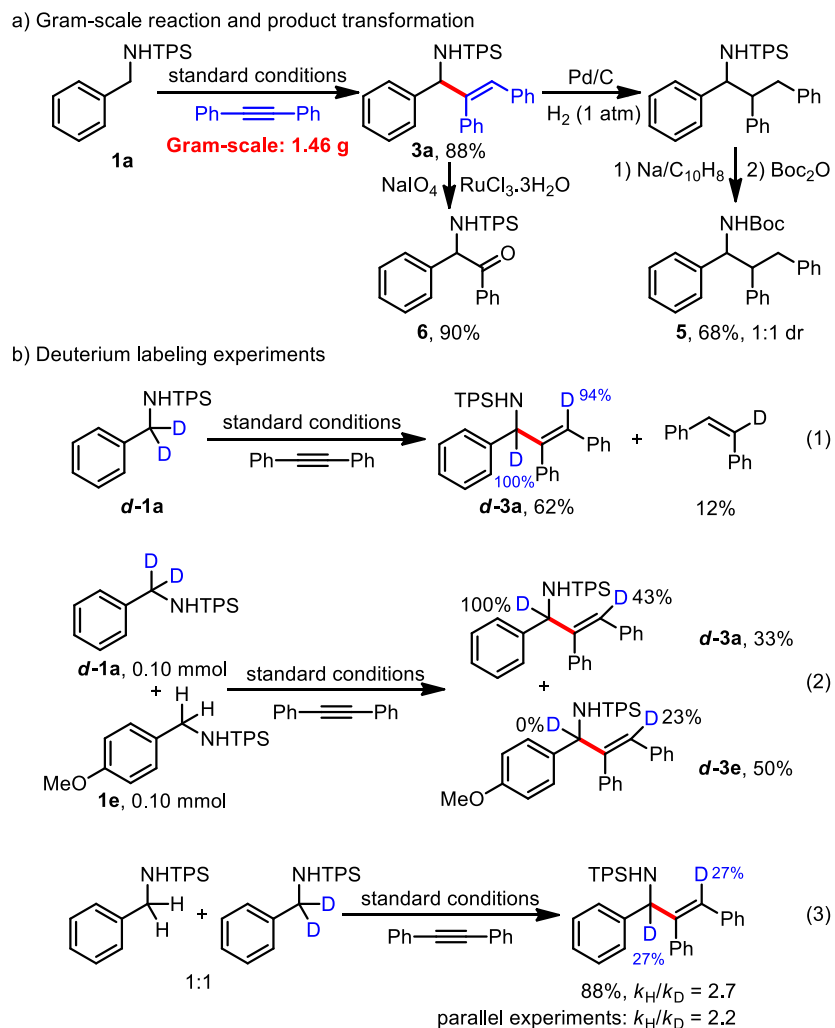

c) Detection of imine 1 $v^{\prime}$

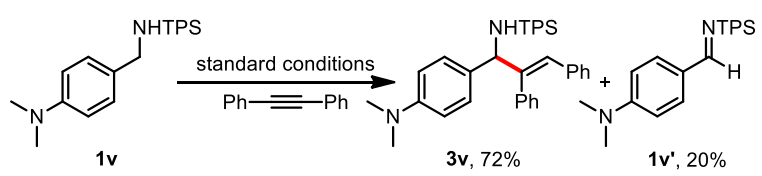

d) Competitive reaction between amide $\mathbf{1 a}$ and imine $\mathbf{1} \mathbf{b}^{\prime}$

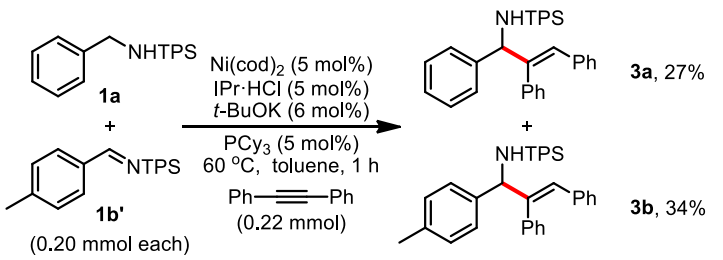

e) Reaction of nickelacycle with amide 1a<smiles>Cc1ccc(C2C(c3ccccc3)=C(c3ccccc3)N(C(F)(F)F)C2NC(F)(F)F)cc1</smiles><smiles>Cc1ccc(C(N[P+](F)(F)F)C(=CPc2ccccc2)c2ccccc2)cc1</smiles>

To further shed light on each individual elementary step of the catalytic reaction, we performed DFT calculations on the model reaction of $\mathrm{N}$-benzylbenzenesulfonamide and diphenylethyne in the presence of a simplified $\mathrm{Ni} / \mathrm{NHC}$ catalyst (see Figure $\mathrm{S} 1$ for details). At the induction stage, two critical steps were a ligandto-ligand hydrogen transfer (LLHT) via TS1 with an activation Gibbs energy of $14.3 \mathrm{kcal} / \mathrm{mol}$ and an intramolecular hydrogen transfer via TS2 with an overall activation Gibbs energy of 18.1 $\mathrm{kcal} / \mathrm{mol}$. At the product-formation stage, the turnover-limiting transition state is predicted to be the hydrogen transfer transition 
state TS5 with an overall activation Gibbs energy of 24.8 $\mathrm{kcal} / \mathrm{mol}$, which is accordance with the observed kinetic isotopic effect (eq (3)). Notably, an activation Gibbs energy for the transition state of the oxidative cyclometallation (TS3) is $23.7 \mathrm{kcal} / \mathrm{mol}$, which is a little lower than that of TS5. DFT calculations with TPS-protected substrate 1a and IPr ligand indicated that the overall activation Gibbs energy is $22.4 \mathrm{kcal} / \mathrm{mol}$. Replacement of TPS by Ts leads to a higher overall activation Gibbs energy of 24.9 $\mathrm{kcal} / \mathrm{mol}$. These results suggested that, as compared with the Ts group, a ca. 30-fold acceleration effect of the TPS group would be expected at $80^{\circ} \mathrm{C}$, which nicely reproduced the experimentally observed superior performance of the TPS protecting group (Scheme 2, entry 1 versus entry 3 ). In addition, DFT calculations also suggested that $\mathrm{PCy}_{3}$ could not reduce the overall activation Gibbs energy of the [Ni(NHC)]-catalyzed reaction (see Figure S3), which suggests that $\mathrm{PCy}_{3}$ might act as an auxiliary ligand to facilitate the generation of the catalytic species and/or to inhibit catalyst deactivation in the reaction.

\section{Scheme 6. Proposed Mechanism and DFT Calculations}

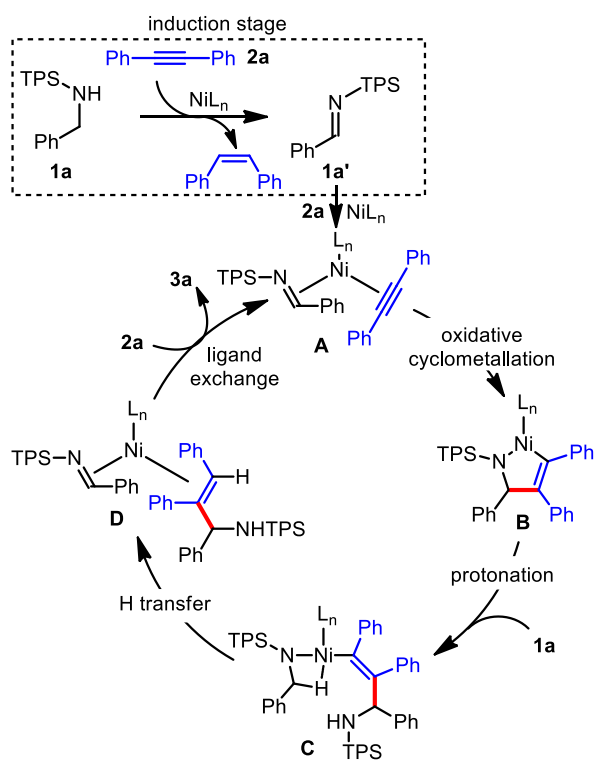

\section{ORCID}

Yu-Xin Luan: 0000-0001-5364-4895

Yi Wang: 0000-0001-5762-5958

Zhi-Xiang Yu: 0000-0003-0939-9727

\section{Notes}

The authors declare no competing financial interests.

\section{ACKNOWLEDGMENT}

This work was supported by the National Natural Science Foundation of China (21672107, 21871145, 21933003, and 91856104), the Fundamental Research Funds for the Central Universities (63191601), High-Performance Computing Platform of Peking University, and National Supercomputing Center in Shenzhen (Shenzhen Cloud Computing Center).

\section{REFERENCES}

(1) (a) Salvatore, R. N.; Yoon, C. H.; Jung, K. W. Synthesis of secondary amines. Tetrahedron 2001, 57, 7785-7811. (b) Lawrence, S. A. Amines: Synthesis, properties and applications; Cambridge University Press: Cambridge, U.K., 2004. (c) Baumann, M.; Baxendale, I. R.; Ley, S. V.; Nikbin, N. An overview of the key routes to the bestselling 5membered ring heterocyclic pharmaceuticals. Beilstein J. Org. Chem. 2011, 7, 442-495. (d) Vitaku, E.; Smith, D. T.; Njardarson, J. T. Analysis of the structural diversity, substitution patterns, and frequency of nitrogen heterocycles among U.S. FDA approved pharmaceuticals. J. Med. Chem. 2014, 57, 10257-10274.

(2) For selected reviews on $\alpha-\mathrm{C}-\mathrm{H}$ functionalization of amines, see: (a) Edwards, P. M.; Schafer, L. L. Early transition metal-catalyzed C-H alkylation: hydroaminoalkylation for $\mathrm{C}_{\mathrm{sp} 3}-\mathrm{C}_{\mathrm{sp} 3}$ bond formation in the synthesis of selectively substituted amines. Chem. Commun. 2018, 54, 12543-12560. (b) Cheng, M.-X.; Yang, S.-D. Recent advances in the enantioselective oxidative $\alpha-\mathrm{C}-\mathrm{H}$ functionalization of amines. Synlett 2017, 28, 159-174. (c) Dong, Z.; Ren, Z.; Thompson, S. J.; Xu, Y.; Dong, G. Transition-metal-catalyzed $\mathrm{C}-\mathrm{H}$ alkylation using alkenes. Chem. Rev. 2017, 117, 9333-9403. (d) Seidel, D. The azomethine ylide route to amine $\mathrm{C}-\mathrm{H}$ functionalization: Redox-versions of classic reactions and a pathway to new transformations. Acc. Chem. Res. 2015, 48, 317-328. (e) Girard, S. A.; Knauber, T.; Li, C.-J. The cross-dehydrogenative coupling of $\mathrm{C}_{\mathrm{sp} 3}-\mathrm{H}$ bonds: A versatile strategy for $\mathrm{C}-\mathrm{C}$ bond formations. Angew. Chem. Int. Ed. 2014, 53, 74-100. (f) Shi, L.; Xia, W. Photoredox functionalization of $\mathrm{C}-\mathrm{H}$ bonds adjacent to a nitrogen atom. Chem. Soc. Rev. 2012, 41, 7687-7697. (g) Mitchell, E. A.; Peschiulli, A.; Lefevre, N.; Meerpoel, L.; Maes, B. U. W. Direct $\alpha$-functionalization of saturated cyclic amines. Chem. Eur. J. 2012, 18, 10092-10142. (h) Li, C.-J. Crossdehydrogenative coupling (CDC): Exploring C-C bond formations beyond functional group transformations. Acc. Chem. Res. 2009, 42, 335-344. (i) Campos, K. R. Direct $\mathrm{sp}^{3} \mathrm{C}-\mathrm{H}$ bond activation adjacent to nitrogen in heterocycles. Chem. Soc. Rev. 2007, 36, 1069-1084. (j) Murahashi, S.-I. Synthetic aspects of metal-catalyzed oxidations of amines and related reactions. Angew. Chem. Int. Ed. 1995, 34, 2443-2465.

(3) For selected reviews on $\mathrm{sp}^{3} \mathrm{C}-\mathrm{H}$ activation, see: (a) Labinger, J. A.; Bercaw, J. E. Understanding and exploiting $\mathrm{C}-\mathrm{H}$ bond activation. Nature 2002, 417, 507-514. (b) Davies, H. M. L.; Manning, J. R. Catalytic C-H functionalization by metal carbenoid and nitrenoid insertion. Nature $\mathbf{2 0 0 8}$, 451, 417-424. (c) Chen, X.; Engle, K. M.; Wang, D.-H.; Yu, J.-Q. Palladium(II)-catalyzed $\mathrm{C}-\mathrm{H}$ activation/C-C cross-coupling reactions: Versatility and practicality. Angew. Chem. Int. Ed. 2009, 48, 5094-5115. (d) Jazzar, R.; Hitce, J.; Renaudat, A.; Sofack-Kreutzer, J.; Baudoin, O. Functionalization of organic molecules by transition-metal-catalyzed $\mathrm{C}_{\mathrm{sp} 3}-\mathrm{H}$ activation. Chem. Eur. J. 2010, 16, 2654-2672. (e) Lyons, T. W.; Sanford, M. S. Palladium-catalyzed ligand-directed $\mathrm{C}-\mathrm{H}$ functionalization reactions. Chem. Rev. 2010, 110, 1147-1169. (f) Li, H.; Li, B.-J.; Shi, Z.-J. Challenge and progress: palladium-catalyzed $\mathrm{sp}^{3} \mathrm{C}-\mathrm{H}$ activation. Catal. Sci. Technol. 2011, 1, 191-206. (g) Baudoin, O. Transition metalcatalyzed arylation of unactivated $\mathrm{C}\left(\mathrm{sp}^{3}\right)-\mathrm{H}$ bonds. Chem. Soc. Rev. 2011, 40, 4902-4911. (h) Chen, G.; Shi, Z.-J. Privileged strategies for direct transformations of inert aliphatic $\mathrm{C}-\mathrm{H}$ bonds. Nat. Sci. Rev. 2014, 1, 172-175. (i) Qiu, G.; Wu, J. Transition metal-catalyzed direct remote $\mathrm{C}-\mathrm{H}$ functionalization of alkyl groups via $\mathrm{C}\left(\mathrm{sp}^{3}\right)-\mathrm{H}$ bond activation. Org. Chem. Front. 2015, 2, 169-178. (j) Yang, L.; Huang, H. Transition-metalcatalyzed direct addition of unactivated $\mathrm{C}-\mathrm{H}$ bonds to polar unsaturated

\section{Corresponding Authors}

*yxluan@nankai.edu.cn

*yuzx@pku.edu.cn

*mcye@nankai.edu.cn 
bonds. Chem. Rev. 2015, 115, 3468-3517. (k) Hartwig, J. F. Evolution of $\mathrm{C}-\mathrm{H}$ bond functionalization from methane to methodology. J. Am. Chem Soc. 2016, 138, 2-24. (1) Jiang, Y.-Y.; Man, X.; Bi, S. Advances in theoretical study on transition-metal-catalyzed $\mathrm{C}-\mathrm{H}$ activation. Sci. China Chem. 2016, 59, 1448-1466. (m) Kim, D.-S.; Park, W.-J.; Jun, C.-H. Metal-organic cooperative catalysis in $\mathrm{C}-\mathrm{H}$ and $\mathrm{C}-\mathrm{C}$ bond activation. Chem. Rev. 2017, 117, 8977-9015. (n) Timsina, Y. N. ; Gupton, B. F.; Ellis, K. C. Palladium-catalyzed $\mathrm{C}-\mathrm{H}$ amination of $\mathrm{C}\left(\mathrm{sp}^{2}\right)$ and $\mathrm{C}\left(\mathrm{sp}^{3}\right)-\mathrm{H}$ Bonds: Mechanism and scope for N-based molecule synthesis. ACS Catal. 2018, 8, 5732-5776. (o) Rej, S.; Chatani, N. Rhodium-catalyzed $\mathrm{C}\left(\mathrm{sp}^{2}\right)$ or $\mathrm{C}\left(\mathrm{sp}^{3}\right)-\mathrm{H}$ bond functionalization assisted by removable directing groups. Angew. Chem. Int. Ed. 2019, 58, 8304-8329.

(4) For a relevant review on secondary $\mathrm{sp}^{3} \mathrm{C}-\mathrm{H}$ activation, see: (a) Herrmann, P.; Bach, T. Diastereotopos-differentiating $\mathrm{C}-\mathrm{H}$ activation reactions at methylene groups. Chem. Soc. Rev. 2011, 40, 2022-2038. For selected recent examples, see: (b) Chen, G.; Gong, W.; Zhang, Z.; Andrä, M. S.; Chen, Y.-Q.; Hong, X.; Yang, Y.-F.; Liu, T.; Houk, K. N.; Yu, J.Q. Ligand-accelerated enantioselective methylene $\mathrm{C}\left(\mathrm{sp}^{3}\right)-\mathrm{H}$ bond activation. Science 2016, 353, 1023-1027. (c) Zhang, F.-L.; Hong, K.; Li, T.-J.; Park, H.; Yu, J.-Q. Functionalization of $\mathrm{C}\left(\mathrm{sp}^{3}\right)-\mathrm{H}$ bonds using a transient directing group. Science 2016, 351, 252-256. (d) Andrä, M. S.; Schifferer, L.; Pollok, C. H.; Merten, C.; Gooßen, L. J.; Yu, J.-Q. Enantio- and diastereo switchable $\mathrm{C}-\mathrm{H}$ arylation of methylene groups in cycloalkanes. Chem. Eur. J. 2019, 25, 8503-8507.

(5) For selected examples on directed $\alpha-\mathrm{C}-\mathrm{H}$ alkylation of amines, see: (a) Jun, C.-H.; Hwang, D.-C.; Na, S.-J. Chelation-assisted alkylation of benzylamine derivatives by $\mathrm{Ru}^{0}$ catalyst. Chem. Commun. 1998, 1405-1406. (b) Chatani, N.; Asaumi, T.; Yorimitsu, S.; Ikeda, T.; Kakiuchi, F.; Murai, S. $\mathrm{Ru}_{3}(\mathrm{CO})_{12}$-catalyzed coupling reaction of $\mathrm{sp}^{3} \mathrm{C}-\mathrm{H}$ bonds adjacent to a nitrogen atom in alkylamines with alkenes. J. Am. Chem. Soc. 2001, 123, 10935-10941. (c) Pastine, S. J.; Gribkov, D. V.; Sames, D. $\mathrm{sp}^{3} \mathrm{C}-\mathrm{H}$ bond arylation directed by amidine protecting group: $\alpha-$ Arylation of pyrrolidines and piperidines. J. Am. Chem. Soc. 2006, 128, 14220-14221. (d) Pan, S.; Endo, K.; Shibata, T. Ir(I)-Catalyzed enantioselective secondary $\mathrm{sp}^{3} \mathrm{C}-\mathrm{H}$ bond activation of 2-(alkylamino)pyridines with alkenes. Org. Lett. 2011, 13, 4692-4695. (e) Bergman, S. D.; Storr, T. E.; Prokopcova, H.; Aelvoet, K.; Diels, G.; Meerpoel, L.; Maes, B. U. $\mathrm{W}$. The role of the alcohol and carboxylic acid in directed rutheniumcatalyzed $\mathrm{C}\left(\mathrm{sp}^{3}\right)-\mathrm{H} \alpha$-alkylation of cyclic amines. Chem. Eur. J. 2012, 18, 10393-10398. (f) Yan, H.; Lu, 1.; Rong, G.; Liu, D.; Zheng, Y.; Chen, J.; Mao, J. Functionalization of amides via copper-catalyzed oxyalkylation of vinylarenes and decarboxylative alkenylation of $\mathrm{sp}^{3} \mathrm{C}-\mathrm{H}$. J. Org. Chem. 2014, 79, 7103-7111. (g) Schinkel, M.; Wang, L.; Bielefeld, K.; Ackermann, L. Ruthenium(II)-catalyzed $\mathrm{C}\left(\mathrm{sp}^{3}\right)-\mathrm{H} \alpha$-alkylation of pyrrolidines. Org. Lett. 2014, 16, 1876-1879. (h) Lahm, G.; Opatz, T. Unique regioselectivity in the $\mathrm{C}\left(\mathrm{sp}^{3}\right)-\mathrm{H} \alpha$-alkylation of amines: The benzoxazole moiety as a removable directing group. Org. Lett. 2014, 16, 4201-4203. (i) Tahara, Y.; Michino, M.; Ito, M.; Kanyiva, K. S.; Shitata, T. Enantioselective $\mathrm{sp}^{3} \mathrm{C}-\mathrm{H}$ alkylation of $\gamma$-butyrolactam by a chiral $\operatorname{Ir}(\mathrm{I})$ catalyst for the synthesis of 4-substituted $\gamma$-amino acids. Chem. Commun. 2015, 51, 16660-16663. (j) Yamauchi, D.; Nishimura, T.; Yorimitsu, H. Hydroxoiridium-catalyzed hydroalkylation of terminal alkenes with ureas by $\mathrm{C}\left(\mathrm{sp}^{3}\right)-\mathrm{H}$ bond activation. Angew. Chem. Int. Ed. 2017, 56, 7200-7204. (k) Tran, A. T.; Yu, J.-Q. Practical alkoxythiocarbonyl auxiliaries for iridium(I)-catalyzed $\mathrm{C}-\mathrm{H}$ alkylation of azacycles. Angew. Chem. Int. Ed. 2017, 56, 10530-10534. (1) Nakamura, I.; Yamauchi, D.; Nishimura, T. Hydroxoiridium-catalyzed $\mathrm{sp}^{3} \mathrm{C}-\mathrm{H}$ alkylation of indoline derivatives with terminal alkenes. Asian J. Org. Chem. 2018, 7, 1347-1350. (m) Gonnard, L.; Guerinot, A.; Cossy, J. Transition metal-catalyzed $\alpha$-alkylation of amines by $\mathrm{C}\left(\mathrm{sp}^{3}\right)-\mathrm{H}$ bond activation. Tetrahedron 2019, 75, 145-163.

(6) For selected reviews on non-directed $\alpha-\mathrm{C}-\mathrm{H}$ alkylation of amines through early transition metal catalysis, see: (a) Hannedouche, J.; Schulz, E. Hydroamination and hydroaminoalkylation of alkenes by group 3-5 elements: Recent developments and comparison with late transition metals. Organometallics 2018, 37, 4313-4326. (b) Ryken, S. A.; Schafer, L. L. N,O-Chelating four-membered metallacyclic titanium(IV) complexes for atom-economic catalytic reactions. Acc. Chem. Res. 2015, 48, 2576-2586. (c) Chong, E.; Garcia, P.; Schafer, L. L. Hydroaminoalkylation: Early-transition-metal-catalyzed $\alpha$-alkylation of amines. Synthesis 2014, 46, 2884-2896. (d) Waterman, R. $\sigma$-Bond metathesis: A 30-year retrospective. Organometallics 2013, 32, 7249-7263. (e) Eisenberger, P.; Schafer, L. L. Catalytic synthesis of amines and $N$-containing heterocycles: Amidate complexes for selective $\mathrm{C}-\mathrm{N}$ and $\mathrm{C}-\mathrm{C}$ bond-forming reactions. Pure Appl. Chem. 2010, 82, 1503-1515. (f) Roesky, P. W. Catalytic hydroaminoalkylation. Angew. Chem. Int. Ed. 2009, 48, 4892-4894. For selected examples on various early transition metal catalysis, see: (g) Gao, H.; Su, J.; Xu, P.; Xu, X. Scandium-catalyzed C $\left(\mathrm{sp}^{3}\right)-\mathrm{H}$ alkylation of $N, N-$ dimethyl anilines with alkenes. Org. Chem. Front. 2018, 5, 59-63. (h) Liu, F.; Luo, G.; Hou, Z.; Luo, Y. Mechanistic insights into scandiumcatalyzed hydroaminoalkylation of olefins with amines: Origin of regioselectivity and charge-based prediction model. Organometallics 2017, 36, 1557-1565. (i) Nako, A. E.; Oyamada, J.; Nishiura, M.; Hou, Z. Scandium-catalysed intermolecular hydroaminoalkylation of olefins with aliphatic tertiary amines. Chem. Sci. 2016, 7, 6429-6434. (j) Bielefeld, J.; Doye, S. Dimethylamine as a substrate in hydroaminoalkylation reactions. Angew. Chem. Int. Ed. 2017, 56, 15155-15158. (k) Manßen, M.; Lauterbach, N.; Dörfler, J.; Schmidtmann, M.; Saak, W.; Doye, S.; Beckhaus, R. Efficient access to titanaaziridines by $\mathrm{C}-\mathrm{H}$ activation of $\mathrm{N}$-methylanilines at ambient temperature. Angew. Chem. Int. Ed. 2015, 54, 4383-4387. (1) Bexrud, J. A.; Eisenberger, P.; Leitch, D. C.; Payne, P. R.; Schafer, L. L. Selective $\mathrm{C}-\mathrm{H}$ activation $\alpha$ to primary amines. Bridging metallaaziridines for catalytic, intramolecular $\alpha$-alkylation. J. Am. Chem. Soc. 2009, 131, 2116-2118. (m) Hamzaoui, B.; Pelletier, J. D. A.; El Eter, M.; Chen, Y.; Abou-Hamad, E.; Basset, J.-M. Isolation and characterization of welldefined silica-supported azametallacyclopentane: A key intermediate in catalytic hydroaminoalkylation reactions. Adv. Synth. Catal. 2015, 357, 3148-3154. (n) Herzon, S. B.; Hartwig, J. F. Direct, Catalytic hydroaminoalkylation of unactivated olefins with $\mathrm{N}$-alkyl arylamines. J. Am. Chem. Soc. 2007, 129, 6690-6691. (o) Herzon, S. B.; Hartwig, J. F. Hydroaminoalkylation of unactivated olefins with dialkylamines. J. Am. Chem. Soc. 2008, 130, 14940-14941. (p) DiPucchio, R. C.; Rosca, S.-C.; Schafer, L. L. Catalytic and atom-economic $\mathrm{C}_{\mathrm{sp} 3}-\mathrm{C}_{\mathrm{sp} 3}$ bond formation: Alkyl tantalum ureates for hydroaminoalkylation. Angew. Chem. Int. Ed. 2018, 57, 3469-3472. (q) Brandt, J. W.; Chong, E.; Schafer, L. L. Ligand effects and kinetic investigations of sterically accessible 2-pyridonate tantalum complexes for hydroaminoalkylation. ACS Catal. 2017, 7, 6323-6330.

(7) For selected examples on non-directed $\alpha-\mathrm{C}-\mathrm{H}$ alkylation of amines through late transition metals, see: (a) Schmitt, D. C.; Lee, J.; DechertSchmitt, A.-M. R.; Yamaguchi, E.; Krische, M. J. Ruthenium catalyzed hydroaminoalkylation of isoprene via transfer hydrogenation: byproductfree prenylation of hydantoins. Chem. Commun. 2013, 49, 6096-6098. For a relevant review, see: (b) Perez, F.; Oda, S.; Geary, L. M.; Krische, M. J. Ruthenium-catalyzed transfer hydrogenation for $\mathrm{C}-\mathrm{C}$ bond formation: Hydrohydroxyalkylation and hydroaminoalkylation via reactant redox pairs. Top. Curr. Chem. 2016, 374, 35-57.

(8) For selected examples on directed $\alpha-\mathrm{C}-\mathrm{H}$ arylation of amines, see: (a) Pastine, S. J.; Gribkov, D. V.; Sames, D. $\mathrm{sp}^{3} \mathrm{C}-\mathrm{H}$ Bond arylation directed by amidine protecting group: $\alpha$-Arylation of pyrrolidines and piperidines. J. Am. Chem. Soc. 2006, 128, 14220-14221. (b) Prokopcova, H.; Bergman, S. D.; Avelvoet, K.; Smout, V.; Herrebout, W.; van der Veken, B.; Meerpoel, L.; Maes, B. U. W. C-2 Arylation of piperidines through directed transition-metal-catalyzed $\mathrm{sp}^{3} \mathrm{C}-\mathrm{H}$ activation. Chem. Eur. J. 2010, 16, 13063-13067. (c) Dastbaravardeh, N.; Schnürch, M.; Mihovilovic, M. D. Ruthenium(0)-catalyzed $\mathrm{sp}^{3} \mathrm{C}-\mathrm{H}$ bond arylation of benzylic amines using arylboronates. Org. Lett. 2012, 14, 1930-1933. (d) Dastbaravardeh, N.; Schnürch, M.; Mihovilovic, M. D. Ruthenium(II)catalyzed $\mathrm{sp}^{3} \mathrm{C}-\mathrm{H}$ bond arylation of benzylic amines using aryl halides. Org. Lett. 2012, 14, 3792-3795. (e) Peschiulli, A.; Smout, V.; Storr, T. E.; Mitchell, E. A.; Elias, Z.; Herrebout, W.; Berthelot, D.; Meerpoel, L.; Maes, B. U. W. Ruthenium-catalyzed $\alpha$-(hetero)arylation of saturated cyclic amines: Reaction scope and mechanism. Chem. Eur. J. 2013, 19, 10378-10387. (f) Kumar, N. Y. P.; Jeyachandran, R.; Ackermann, L. $\mathrm{C}\left(\mathrm{sp}^{3}\right)-\mathrm{H}$ bond arylations catalyzed by well-defined $\left[\mathrm{Ru}\left(\mathrm{O}_{2} \mathrm{CMes}\right)_{2}(p-\right.$ cymene)]. J. Org. Chem. 2013, 78, 4145-4152. (g) Spangler, J. E.; Kobayashi, Y.; Verma, P.; Wang, D.-H.; Yu, J.-Q. $\alpha$-Arylation of saturated azacycles and $N$-methylamines via palladium(II)-catalyzed $\mathrm{C}\left(\mathrm{sp}^{3}\right)-\mathrm{H}$ coupling. J. Am. Chem. Soc. 2015, 137, 11876-11879. (h) Jain, P.; Verma, P.; Xia, G.; Yu, J.-Q. Enantioselective amine $\alpha$-functionalization via palladium-catalysed $\mathrm{C}-\mathrm{H}$ arylation of thioamides. Nat. Chem. 2017, 9, 140-144. (i) Greßies, S.; Klauck, F. J. R.; Kim, J. H.; Daniliuc, C. G.; Glorius, F. Ligand-enabled enantioselective $\mathrm{C}_{\mathrm{sp} 3}-\mathrm{H}$ activation of tetrahydroquinolines and saturated aza-heterocycles by $\mathrm{Rh}^{\mathrm{I}}$. Angew. Chem. Int. Ed. 2018, 57, 9950-9954. (j) Jiang, H.-J.; Zhong, X.-M.; Yu, J.; Zhang, Y.; Zhang, X.; Wu, Y.-D.; Gong, L.-Z. Assembling a hybrid Pd catalyst from a chiral anionic Co ${ }^{\text {III }}$ complex and ligand for asymmetric $\mathrm{C}\left(\mathrm{sp}^{3}\right)-\mathrm{H}$ functionalization. Angew. Chem. Int. Ed. 2019, 58, 1803-1807.

(9) For selected examples on other directed $\mathrm{C}-\mathrm{H}$ functionalizations, see: (a) Kawamorita, S.; Miyazaki, T.; Iwai, T.; Ohmiya, H.; Sawamura, M. Rh-catalyzed borylation of $N$-adjacent $\mathrm{C}\left(\mathrm{sp}^{3}\right)-\mathrm{H}$ bonds with a silicasupported triarylphosphine ligand. J. Am. Chem. Soc. 2012, 134, 
12924-12927. (b) Jovel, I.; Prateeptongkum, S.; Jackstell, R.; Vogl, N.; Weckbecker, C.; Beller, M. $\alpha$-Functionalization of non-activated aliphatic amines: Ruthenium-catalyzed alkynylations and alkylations. Chem. Commun. 2010, 46, 1956-1958.

(10) Only two examples on primary $\mathrm{sp}^{3} \mathrm{C}-\mathrm{H}$ alkenylation were achieved, see: (a) Tsuchikama, K.; Kasagawa, M.; Endo, K.; Shibata, T. Cationic $\operatorname{Ir}(\mathrm{I})$-catalyzed $\mathrm{sp}^{3} \mathrm{C}-\mathrm{H}$ bond alkenylation of amides with alkynes. Org. Lett. 2009, 11, 1821-1823. (b) Deng, H.-P.; Fan, X.-Z.; Chen, Z-H.; Xu, Q.-H.; Wu, J. Photoinduced nickel-catalyzed chemo- and regioselective hydroalkylation of internal alkynes with ether and amide $\alpha-$ hetero C(sp $\left.{ }^{3}\right)-H$ bonds. J. Am. Chem. Soc. 2017, 139, 13579-13584.

(11) Sakaguchi, S.; Kubo, T.; Ishii, Y. A three-component coupling reaction of aldehydes, amines, and alkynes. Angew. Chem. Int. Ed. 2001, 40, 2534-2536.

(12) (a) Pan, S.; Matsuo, Y.; Endo, K.; Shibata, T. Cationic iridiumcatalyzed enantioselective activation of secondary $\mathrm{sp}^{3} \mathrm{C}-\mathrm{H}$ bond adjacent to nitrogen atom. Tetrahedron 2012, 68, 9009-9015. (b) Pan, S.; Shibata $\mathrm{T}$. Recent advances in iridium-catalyzed alkylation of $\mathrm{C}-\mathrm{H}$ and $\mathrm{N}-\mathrm{H}$ bonds. ACS Catal. 2013, 3, 704-712. For intramolecular annulations, see: (c) Shibata, T. Hirashima, H.; Kasagawa, M.; Tsuchikama, K.; Endo, K. Cationic $\operatorname{Ir}(\mathrm{I})$-catalyzed $\mathrm{sp}^{3} \mathrm{C}-\mathrm{H}$ bond alkenylation of ureas with alkynes for the synthesis of 2,3-disubstituted indoles. Synlett 2011, 2171-2176. (d) DeBoef, B.; Pastine, S. J.; Sames, D. Cross-coupling of $\mathrm{sp}^{3} \mathrm{C}-\mathrm{H}$ bonds and alkenes: Catalytic cyclization of alkene-amide substrates. $J . A m$. Chem. Soc. 2004, 126, 6556-6557.

(13) Buchwald, S. L.; Watson, B. T.; Wannamaker, M. W.; Dewan, J. C. Zirconocene complexes of imines: General synthesis, structure, reactivity, and in situ generation to prepare geometrically pure allylic amines. $J$. Am. Chem. Soc. 1989, 111, 4486-4494.

(14) (a) Grossman, R. B.; Davis, W. M.; Buchwald, S. L. Enantioselective, zirconium-mediated synthesis of allylic amines. J. Am. Chem. Soc. 1991, 113, 2321-2322. (b) Coles, N.; Harris, M. C. J.; Whitby, R. J.; Blagg, J. Structure-reactivity correlations for the formation of zirconocene $\eta^{2}$-imine complexes from amines. Organometallics 1994, 13, 190-199. (c) Harris, M. C. J.; Whitby, R. J.; Blagg, J. A practical procedure for the elaboration of amines via zirconocene $\eta^{2}$-imine complexes. Tetrahedron Lett. 1994, 35, 2431-2434. (d) Gao, Y.; Yoshida, Y.; Sato, F. In situ generation of titanium-imine complexes from imines and $\mathrm{Ti}\left(\mathrm{O}^{i} \mathrm{Pr}\right)_{4} / 2^{i} \mathrm{PrMgX}$, and their reactions with alkynes, nitriles and imines. Synlett 1997, 1353-1354. (e) Barluenga, J.; Rodriguez, F.; Alvarez-Rodrigo, L.; Zapico, J. M.; Fananas, F. J. Zirconium-mediated coupling reactions of amines and enol or allyl ethers: Synthesis of allyl- and homoallylamines. Chem. Eur. J. 2004, 10, 109-116.

(15) Bahena, E. N.; Griffin, S. E.; Schafer, L. L. Zirconium-Catalyzed Hydroaminoalkylation of Alkynes for the Synthesis of Allylic Amines. $J$. Am. Chem. Soc. 10.1021/jacs.0c10405.

(16) For $\alpha$-alkenylation of amines by other methods, see: (a) Sølvhøj, A.; Ahlburg, A.; Madsen, R. Dimethylzinc-initiated radical coupling of $\beta$ bromostyrenes with ethers and amines. Chem. Eur. J. 2015, 21, 16272-16279. (b) Wei, G.; Zhang, C.; Bures, F.; Ye, X.; Tan, C.-H.; Jiang, Z. Enantioselective aerobic oxidative $\mathrm{C}\left(\mathrm{sp}^{3}\right)-\mathrm{H}$ olefination of amines via cooperative photoredox and asymmetric catalysis. ACS Catal. 2016, 6, 3708-3712. (c) Amaoka, Y.; Nagatomo, M.; Watanabe, M.; Tao, K.; Kamijo, S.; Inoue, M. Photochemically induced radical alkenylation of C(sp $\left.{ }^{3}\right)-\mathrm{H}$ bonds. Chem. Sci., 2014, 5, 4339-4345. (d) Paul, S.; Guin, J. Radical $\mathrm{C}\left(\mathrm{sp}^{3}\right)-\mathrm{H}$ alkenylation, alkynylation and allylation of ethers and amides enabled by photocatalysis. Green Chem. 2017, 19, 2530-2534. (e) Chen, W.; Ma, L.; Paul, A.; Seidel, D. Direct $\alpha-\mathrm{C}-\mathrm{H}$ bond functionalization of unprotected cyclic amines. Nat. Chem. 2018, 10, 165-169. (f) Paul, A.; Seidel, D. $\alpha$-Functionalization of cyclic secondary amines: Lewis acid promoted addition of organometallics to transient imines. J. Am. Chem. Soc. 2019, 141, 8778-8782. For selective reductive couplings of alkynes and imines to allylic amines, see: (g) Patel, S. J.; Jamison, T. F. Catalytic three-component coupling of alkynes, imines, and organoboron reagents. Angew. Chem. Int. Ed. 2003, 42, 1364-1367. (h) Kong, J.-R.; Cho, C.-W.; Krische, M. J. Hydrogen-mediated reductive coupling of conjugated alkynes with ethyl ( $N$-sulfinyl)iminoacetates: Synthesis of unnatural $\alpha$ amino acids via rhodium-catalyzed $\mathrm{C}-\mathrm{C}$ bond forming hydrogenation. $J$. Am. Chem. Soc. 2005, 127, 11269-11276. (i) Barchuk, A.; Ngai, M.-Y.; Krische, M. J. Allylic amines via iridium-catalyzed C-C bond forming hydrogenation: Imine vinylation in the absence of stoichiometric byproducts or metallic reagents. J. Am. Chem. Soc. 2007, 129, 8432-8433. (j) Ngai, M.-Y.; Barchuk, A.; Krische, M. J. Enantioselective iridiumcatalyzed imine vinylation: Optically enriched allylic amines via alkyneimine reductive coupling mediated by hydrogen. J. Am. Chem. Soc. 2007,
129, 12644-12645. (k) Skucas, E.; Kong, J. R.; Krische, M. J. Enantioselective reductive coupling of acetylene to $N$-arylsulfonyl imines via rhodium catalyzed $\mathrm{C}-\mathrm{C}$ bond-forming hydrogenation: (Z)-Dienyl allylic amines. J. Am. Chem. Soc. 2007, 129, 7242-7243. (1) Zhou, C.-Y.; Zhu, S.-F.; Wang, L.-X.; Zhou, Q.-L. Enantioselective nickel-catalyzed reductive coupling of alkynes and imines. J. Am. Chem. Soc. 2010, 132, 10955-10957. For an oxidative alkenylation with no selectivity, see: (m) Sun, M.; Wu, H.; Bao, W. $\alpha$-Vinylation of amides with arylacetylenes: synthesis of allylamines under metal-free conditions. Org. Biomol. Chem. 2013, 11, 7076-7079.

(17) For Ni-catalyzed redox-neutral coupling of alcohols and alkynes, see: (a) Nakai, K.; Yoshida, Y.; Kurahashi, T.; Matsubara, S. Nickelcatalyzed redox-economical coupling of alcohols and alkynes to form allylic alcohols. J. Am. Chem. Soc. 2014, 136, 7797-7800. Most recent asymmetric version was reported by Shi and co-workers, see: (b) Cai, Y.; Zhang, J.-W.; Li, F.; Liu, J.-M.; Shi, S.-L. Nickel/ $N$-heterocyclic carbene complex-catalyzed enantioselective redox-neutral coupling of benzyl alcohols and alkynes to allylic alcohols. ACS Catal. 2019, 9, 1-6.

(18) For Ru-catalyzed redox-neutral coupling of alcohols and alkynes, see: (a) Patman, R. L.; Chaulagain, M. R.; Williams, V. M.; Krische, M. J. Direct vinylation of alcohols or aldehydes employing alkynes as vinyl donors: A ruthenium catalyzed $\mathrm{C}-\mathrm{C}$ bond-forming transfer hydrogenation. J. Am. Chem. Soc. 2009, 131, 2066-2067. (b) McInturff, E. L.; Nguyen, K. D.; Krische, M. J. Redox-triggered $\mathrm{C}-\mathrm{C}$ coupling of diols and alkynes: Synthesis of $\beta, \gamma$-unsaturated $\alpha$-hydroxyketones and furans by rutheniumcatalyzed hydrohydroxyalkylation. Angew. Chem. Int. Ed. 2014, 53, 3232-3235. (c) Sato, H.; Bender, M.; Chen, W.; Krische, M. J. Diols, $\alpha-$ ketols, and diones as $22 \pi$ components in $[2+2+2]$ cycloadditions of 1,6 diynes via ruthenium(0)-catalyzed transfer hydrogenation. J. Am. Chem. Soc. 2016, 138, 16244-16247. (d) Luong, T.; Chen, S.; Qu, K.; McInturff, E. L.; Krische, M. J. Ruthenium(0)-catalyzed $\mathrm{C}-\mathrm{C}$ coupling of alkynes and 3-hydroxy-2-oxindoles: Direct $\mathrm{C}-\mathrm{H}$ vinylation of alcohols. Org. Lett. 2017, 19, 966-968.

(19) (a) Ogoshi, S.; Ikeda, H.; Kurosawa, H. Formation of an azanickelacycle by reaction of an imine and an alkyne with nickel(0): Oxidative cyclization, insertion, and reductive elimination. Angew. Chem. Int. Ed. 2007, 46, 4930-4932. (b) Ogoshi, S.; Ikeda, H.; Kurosawa, H. Nickelcatalyzed $[2+2+2]$ cycloaddition of two alkynes and an imine. Pure Appl. Chem. 2008, 80, 1115-1125. (c) Hoshimoto, Y.; Ohata, T.; Ohashi, M.; Ogoshi, S. Nickel-catalyzed synthesis of $N$-aryl-1,2-dihydropyridines by $[2+2+2]$ cycloaddition of imines with alkynes through T-shaped 14electron aza-nickelacycle key intermediates. Chem. Eur. J. 2014, 20, 4105-4110.

(20) (a) McCarren, P. R.; Liu, P.; Cheong, P. H.-Y.; Jamison, T. F.; Houk, K. N. Mechanism and transition-state structures for nickelcatalyzed reductive alkyne-aldehyde coupling reactions. J. Am. Chem. Soc. 2009, 131, 6654-6655. (b) Guihaumé, J.; Halbert, S.; Eisenstein, O.; Perutz, R. N. Hydrofluoroarylation of alkynes with Ni catalysts. C-H activation via ligand-to-ligand hydrogen transfer, an alternative to oxidative addition. Organometallics 2012, 31, 1300-1314. (c) Xiao, L.-J.; Zhao, C.-Y.; Cheng, L.; Feng, B.-Y.; Feng, W.-M.; Xie, J.-H.; Xu, X.-F.; Zhou, Q.-L. Nickel(0)-catalyzed hydroalkenylation of imines with styrene and its derivatives. Angew. Chem., Int. Ed. 2018, 57, 3396-3400. 


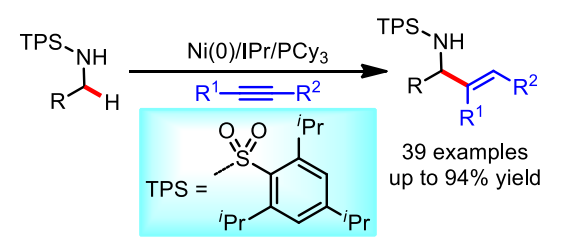

